\title{
p38 mediates mechanical allodynia in a mouse model of type 2 diabetes
}

\author{
Hsinlin T Cheng*, Jacqueline R Dauch, Sang Su Oh, John M Hayes, Yu Hong, Eva L Feldman
}

\begin{abstract}
Background: Painful Diabetic Neuropathy (PDN) affects more than 25\% of patients with type 2 diabetes; however, the pathogenesis remains unclear due to lack of knowledge of the molecular mechanisms leading to PDN. In our current study, we use an animal model of type 2 diabetes in order to understand the roles of p38 in PDN. Previously, we have demonstrated that the C57BLK db/db (db/db) mouse, a model of type 2 diabetes that carries the loss-of-function leptin receptor mutant, develops mechanical allodynia in the hind paws during the early stage (6-12 wk of age) of diabetes. Using this timeline of PDN, we can investigate the signaling mechanisms underlying mechanical allodynia in the $\mathrm{db} / \mathrm{db}$ mouse.

Results: We studied the role of p38 in lumbar dorsal root ganglia (LDRG) during the development of mechanical allodynia in $\mathrm{db} / \mathrm{db}$ mice. p38 phosphorylation was detected by immunoblots at the early stage of mechanical allodynia in LDRG of diabetic mice. Phosphorylated p38 (pp38) immunoreactivity was detected mostly in the smallto medium-sized LDRG neurons during the time period of mechanical allodynia. Treatment with an antibody against nerve growth factor (NGF) significantly inhibited p38 phosphorylation in LDRG of diabetic mice. In addition, we detected higher levels of inflammatory mediators, including cyclooxygenase (COX) 2, inducible nitric oxide synthases (iNOS), and tumor necrosis factor (TNF)- $\alpha$ in LDRG neurons of $\mathrm{db} / \mathrm{db}$ mice compared to non-diabetic $\mathrm{db}$ + mice. Intrathecal delivery of SB203580, a p38 inhibitor, significantly inhibited the development of mechanical allodynia and the upregulation of COX2, iNOS and TNF- $\alpha$.
\end{abstract}

Conclusions: Our findings suggest that NGF activated-p38 phosphorylation mediates mechanical allodynia in the $\mathrm{db} / \mathrm{db}$ mouse by upregulation of multiple inflammatory mediators in LDRG.

\section{Background}

Diabetic neuropathy affects up to $50 \%$ of patients with either type 1 or type 2 diabetes [1,2]. Among the multiple symptoms of diabetic neuropathy, painful diabetic neuropathy (PDN) is the most devastating complication of diabetes [3]. Although there are multiple presentations of PDN in diabetic patients, the most common symptoms of PDN result from a length-dependent polyneuropathy starting at the longest axonal terminals in the feet and extending toward the body [3]. The upper extremities become affected in a similar fashion as the disease progresses, eventually forming the characteristic glove and stocking distribution of sensory symptoms $[1,2]$. It is believed that PDN is an early component of diabetic neuropathy $[4,5]$. PDN is detected more

\footnotetext{
* Correspondence: chengt@umich.edu

Department of Neurology, University of Michigan Medical Center, Ann Arbor, Michigan, USA
}

frequently in patients with prediabetic condition or impaired glucose tolerance than in patients with latestage diabetes [5]. Similar to other types of neuropathic pain, PDN has features of allodynia and hyperalgesia [6]. Allodynia is defined as increased nociceptive perception to normally innocuous stimuli and hyperalgesia indicates increased nociception to normally painful stimuli. Although PDN is a common symptom among diabetic patients, its mechanisms remain unclear. Current treatments for PDN are not effective and less than $30 \%$ of patients obtain satisfactory pain relief [6].

Mitogen activated protein kinases (MAPK) are a group of intracellular messenger proteins that transmit signals from cell membrane receptors to the nucleus. The MAPK family consists of extracellular signal-regulated protein kinases (ERKs), p38, and c-Jun N-terminal kinase (JNK). All MAPKs are involved in both inflammatory and neuropathic pain $[7,8]$. However, individual 
MAPKs could play distinct roles in different pain models [8]. p38 is a serine-threonine kinase which is activated by phosphorylation and mediates many cellular responses to a variety of chemical and physical insults [9]. In a model of NGF-induced hyperalgesia, p38 is phosphorylated in Trk A-positive small to mediumsized dorsal root ganglian (DRG) neurons and phosphorylated p38 (pp38) mediates NGF-induced upregulation of nociceptive molecules [10]. In addition, peripheral inflammation and axotomy also activate p38 in both DRG neurons and spinal cord microglia [11-13]. Administration of a p38 inhibitor, SB203580, reverses p38-mediated pain in several pain models $[9,14]$. Inhibition of p38 activation prevents the development of PDN in streptozotocin (STZ)-treated animal models of type 1 diabetes [14].

PDN is more prevalent in type 2 than type 1 diabetes [6], yet most published studies for PDN use animal models of type 1 diabetes. Understanding the mechanisms of PDN as it develops in the context of type 2 diabetes could lead to developments of effective treatments to target this devastating disease. We have previously characterized the $\mathrm{db} / \mathrm{db}$ mouse as a model for PDN of type 2 diabetes [15]. The $\mathrm{db} / \mathrm{db}$ mouse carries a homozygous null mutation of the leptin receptor $[16,17]$. We reported that $\mathrm{db} / \mathrm{db}$ mice develop features of PDN, including mechanical allodynia at 6-12 wk of age and evident sensory neuropathy at $24 \mathrm{wk}$ of age $[15,17]$. We reported that the mechanical allodynia in $\mathrm{db} / \mathrm{db}$ mice is concordantly associated increased NGF/Trk A receptor signaling in DRG neurons. In the current study, we examine the roles of p38 in the development of mechanical allodynia in $\mathrm{db} / \mathrm{db}$ mice. We hypothesized that NGF-Trk A signaling could trigger p38 activation and upregulate $\mathrm{p} 38$-depedent nociceptive molecules in LDRG of $\mathrm{db} / \mathrm{db}$ mice. Our findings provide new understanding of the molecular mechanisms of PDN of type 2 diabetes and indicate that $\mathrm{p} 38$ could be a potential target for treating PDN of type 2 diabetes.

\section{Results}

p38 is phosphorylated during the time period of mechanical allodynia

We previously detected the development of mechanical allodynia in $\mathrm{db} / \mathrm{db}$ mice from 6-12 wk of age. The maximum reduction of mechanical pain thresholds was detected at 8 wk of age [15]. In the current study, pp38 immunoblots were performed on LDRG collected at $5,8,10$, and $12 \mathrm{wk}$ of age (Fig. 1). Representative pp38 immunoblots demonstrated increased phosphorylation of p38 in LDRG of the $\mathrm{db} / \mathrm{db}$ mouse model in comparison to the $\mathrm{db}+$ mouse model at 5,8 and $10 \mathrm{wk}$ of age. At 12 wk of age, p38 phosphorylation in $\mathrm{db} / \mathrm{db}$ mice was reduced to the control level (Fig. 1A). There was no difference in levels of total p38 protein expression between $\mathrm{db}+$ and $\mathrm{db} / \mathrm{db}$ mice. Densitometric studies which normalized the levels of pp38 to that of total p38 and actin revealed significantly increased p38 phosphorylation in the $\mathrm{db} / \mathrm{db}$ mouse at 5,8 , and $10 \mathrm{wk}$ of age. No significant difference between the pp38 levels of $\mathrm{db}+$ and $\mathrm{db} / \mathrm{db}$ mice was detected at $12 \mathrm{wk}$ of age (Fig. 1B).

\section{pp38 immunoreactivity is detected in small- to medium-sized LDRG neurons during the time period of mechanical allodynia}

We next localized pp38 in L4-6 DRG using immunohistochemistry (Fig. 2). Only trace amounts of pp38 immunoreactivity were detected in L4-6 DRG of $\mathrm{db}+$ mice (Fig. 2A, arrowhead). In L4-6 DRG of db/db mice, pp38 immunoreactivity was detected mostly in the nuclei of small- to medium-sized neurons (Fig. 2B, arrow). Quantification studies demonstrated that there is a significant increase in the percentage of pp38-positive neurons in $\mathrm{db} / \mathrm{db}$ mice compared to $\mathrm{db}+$ mice of the same age during the period of mechanical allodynia (Fig. 2C). The most prominent increase was detected at $8 \mathrm{wk}$ of age, with a 6 -fold increase in the percentage of pp38-positive neurons in $\mathrm{db} / \mathrm{db}$ mice in comparison to $\mathrm{db}+$ mice. A cell size distribution study detected significant increases of not only the percentages of pp38 positivity in small$(<20 \mu \mathrm{m}$ in diameter) to medium-sized $(20-40 \mu \mathrm{m}$ in diameter) LDRG neurons, but also in large-sized ( $>40 \mu \mathrm{m}$ in diameter) LDRG neurons in $\mathrm{db} / \mathrm{db}$ mice at $8 \mathrm{wk}$ of age (Fig. 2D).

\section{Anti-NGF inhibits the phosphorylation of p38 in $\mathrm{db} / \mathrm{db}$ mice}

Previously, we reported enhanced NGF expression and phosphorylation of Trk A receptors in LDRG of $\mathrm{db} / \mathrm{db}$ mice during the period of mechanical allodynia. The time course of NGF-Trk A signaling parallels the current findings of p38 phosphorylation [15]. To investigate if NGF is an upstream activator of p38 during the period of mechanical allodynia in $\mathrm{db} / \mathrm{db}$ mice, we administered the same anti-NGF antibody used in our previous studies to block the development of mechanical allodynia [15]. Pp38 immunoblots were performed to determine the effects of anti-NGF on p38 phosphorylation in LDRG following 2 weeks of anti-NGF treatment, following the same paradigm as our previous studies [15]. Treatments with anti-NGF at 6 and 7 wk of age significantly decreased the phosphorylation of p38 in LDRG of db/db mice at $8 \mathrm{wk}$ of age (Fig. 3A). Densitometric studies further determined that anti-NGF reversed the $\mathrm{p} 38$ phosphorylation in $\mathrm{db} / \mathrm{db}$ mice but did not affect the baseline p38 phosphorylation in LDRG of $\mathrm{db}+$ nondiabetic mice (Fig. 3B). 



Figure 1 Phosphorylation of p38 during the course of mechanical allodynia. A: Representative immunoblots of pp38, p38 and GAPDH using LDRG extracts from $\mathrm{db}+$ and $\mathrm{db} / \mathrm{db}$ mice at 5, 8, 10, and 12 wk of age. Increased levels of pp38 were detected in $\mathrm{db} / \mathrm{db}$ mice when compared to $\mathrm{db}+$ mice at 5, 8 and $10 \mathrm{wk}$ of age. At $12 \mathrm{wk}$ of age, p38 phosphorylation returned to the control level. In addition, no change in expression levels of p38 was detected in LDRG of $\mathrm{db} / \mathrm{db}$ mice and $\mathrm{db}+$ mice. GAPDH served as the loading control. B: Densitometric analysis of immunoblots using LDRG of $\mathrm{db}+$ and $\mathrm{db} / \mathrm{db}$ mice at 5, 8, 10 and $12 \mathrm{wk}$ of age during the development of mechanical allodynia. Significantly enhanced pp38 levels were detected in db/db mice at 5, 8 and 10 wk of age but not at 12 wk of age. $N=4,{ }^{*} p<0.05$.

Intrathecal administration of SB203580 inhibits p38 phosphorylation and mechanical allodynia

To determine directly if the activation of p38 mediates mechanical allodynia in $\mathrm{db} / \mathrm{db}$ mice, a p38 inhibitor, SB203580, was administered intrathecally via mini osmotic pumps. Minipumps were inserted into both $\mathrm{db}+$ and $\mathrm{db} / \mathrm{db}$ mice at $7 \mathrm{wk}$ of age and delivered SB203580 in artificial CSF with 10\% DMSO at a rate of $0.51 \mu \mathrm{g} / \mathrm{hr}$ for $7 \mathrm{~d}$. Control groups were treated with artificial CSF with 10\% DMSO. Mechanical thresholds were measured at the end of the SB203580 treatment. pp38 immunoblots confirmed the inhibition of p38 phosphorylation in LDRG in response to SB203580 treatment in both $\mathrm{db}+$ and $\mathrm{db} / \mathrm{db}$ mice (Fig. $4 \mathrm{~A}$ ). Densitometric analysis demonstrated a reversal of p38 phosphorylation in $\mathrm{db} / \mathrm{db}$ mice down to the levels observed in the control $\mathrm{db}+$ mice (Fig. $4 \mathrm{~B}$ ). In conjunction with the inhibition of p38 phosphorylation, SB203580 treatment inhibited mechanical allodynia in $\mathrm{db} / \mathrm{db}$ mice (Fig. 4C) and lowered the percentage of substance $\mathrm{P}$ (SP)-positive neurons (Fig. 4D). In contrast, the percentage of Isolectin B-4 (IB4)-labeled neurons was not affected by SB203580 treatment (Fig. 4E).

Intrathecal administration of SB203580 inhibits the upregulation of inflammatory mediators in LDRG of $\mathrm{db} / \mathrm{db}$ mice

To study the downstream molecules of NGF-p38 signaling, we screened several nociceptive molecules reported to be involved in p38-mediated pain, including COX2, iNOS, and TNF- $\alpha$. We first performed RT-PCR to measure the gene expression of these molecules (Fig. 5). Similar patterns of gene regulation were detected for all three proteins. The gene expression of COX2 (Fig. 5A), iNOS (Fig. 5B), and TNF- $\alpha$ (Fig. 5C) were all upregulated in LDRG of $\mathrm{db} / \mathrm{db}$ mice in comparison to the $\mathrm{db}+$ control. SB203580 treatment significantly decreased the upregulation of all three genes (Fig. 5A-C). SB203580 treatment did not affect the gene expression of these molecules in LDRG of $d b+$ mice except in the case of TNF- $\alpha$ (Fig. 5C).

To determine the cellular localization of the p38dependent inflammatory mediators in LDRG, immunohistochemistry studies were performed for iNOS (Fig. 6A, B, C, D), TNF- $\alpha$ (Fig. 6E, F, G, H), CD68 (a macrophage marker, Fig. 6I, 6J, 6K, 6L), and COX2 (Fig. $6 \mathrm{M}, \mathrm{N}, \mathrm{O}, \mathrm{P})$. Both $\mathrm{db}+$ and $\mathrm{db} / \mathrm{db}$ mice were treated with vehicle or vehicle containing SB203580 intrathecally for $1 \mathrm{wk}$. Enhanced immunoreactivity for iNOS, TNF- $\alpha$ and COX2 was detected in LDRG of $\mathrm{db} / \mathrm{db}$ mice when compared to LDRG of $\mathrm{db}+$ mice. The immunopositive cells for iNOS, TNF- $\alpha$, and COX2 are mostly neurons, and include both small- to medium- and large sizes (Fig. $6 \mathrm{C}, \mathrm{G}, \mathrm{K}, \mathrm{O})$. In addition, increased numbers of CD68positive macrophages were detected in $\mathrm{db} / \mathrm{db}$ mouse LDRG, suggesting the involvement of cell-mediated inflammation (Fig. 6K). SB203580 treatment significantly reduced the immunoreactivity of iNOS, TNF- $\alpha$, CD68, and COX2, in DRG neurons of $\mathrm{db} / \mathrm{db}$ mice (compare Fig. $6 \mathrm{C}$ to $6 \mathrm{D}, \mathrm{G}$ to $6 \mathrm{H}, \mathrm{K}$ to $6 \mathrm{~L}$, and $6 \mathrm{O}$ to $6 \mathrm{P}$ ).

We further quantified the numbers of immunopositive LDRG neurons of $\mathrm{db}+$ and $\mathrm{db} / \mathrm{db}$ mice treated with vehicle control and SB203580 for iNOS (Fig. 7A), COX2 

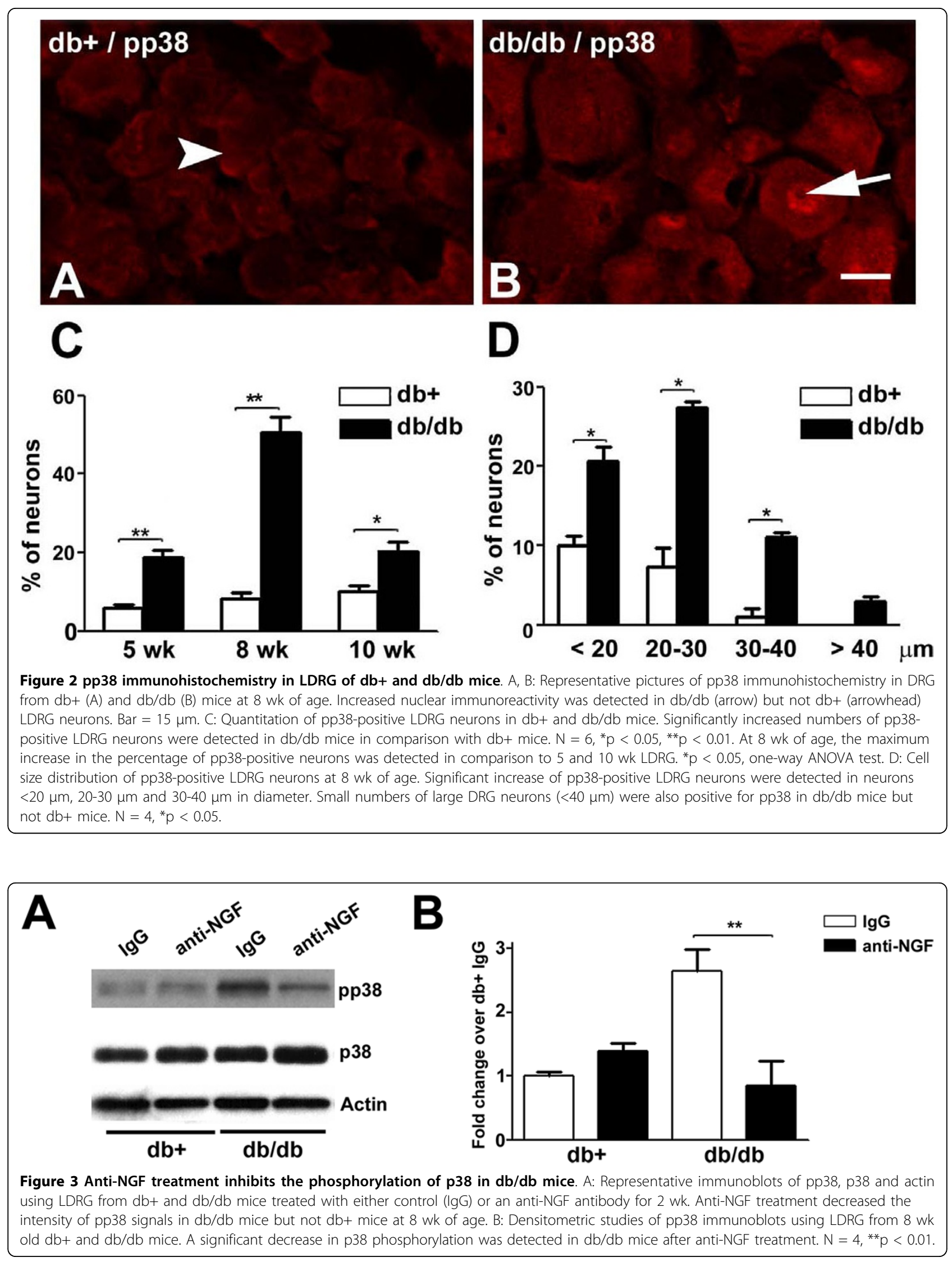


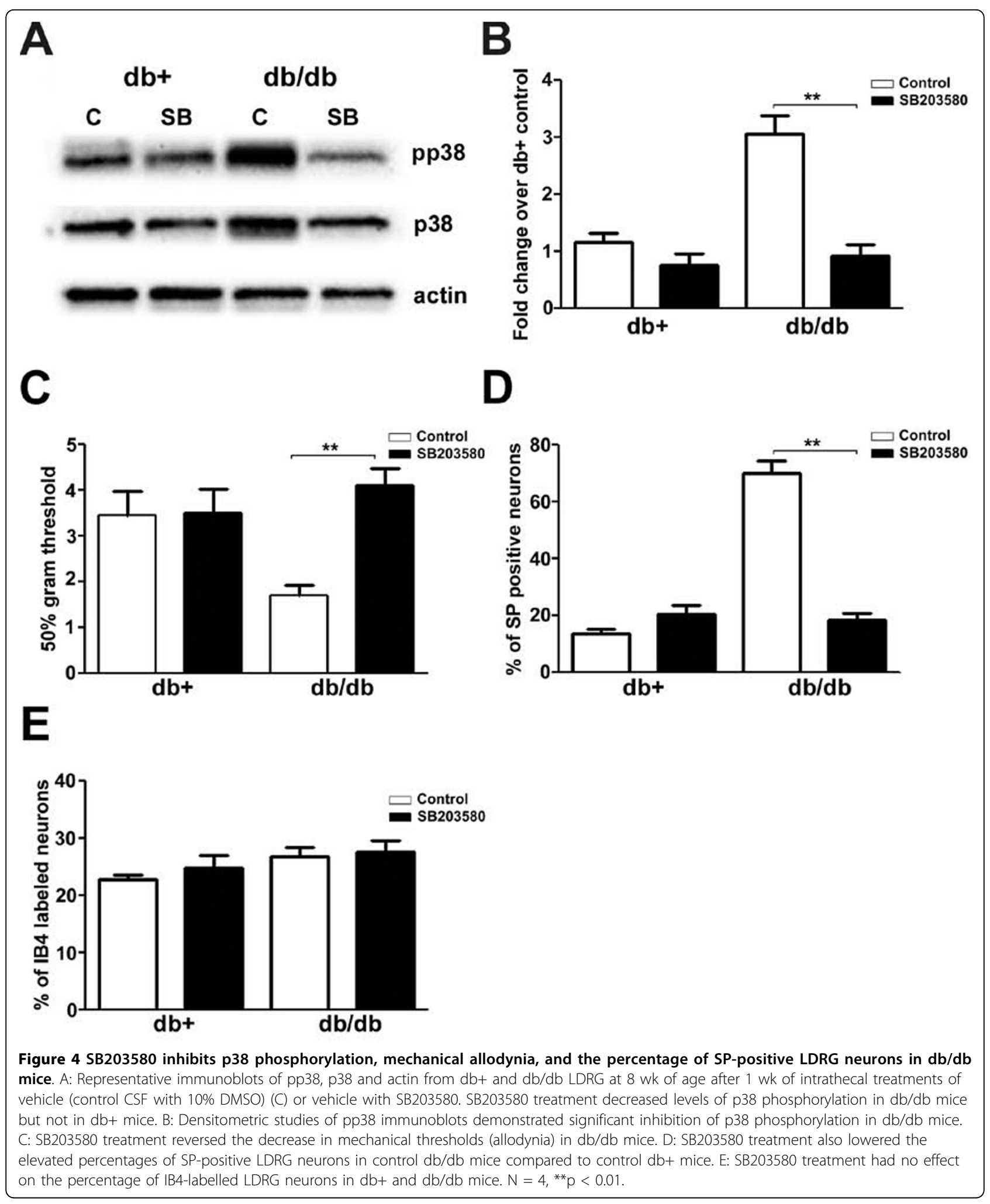




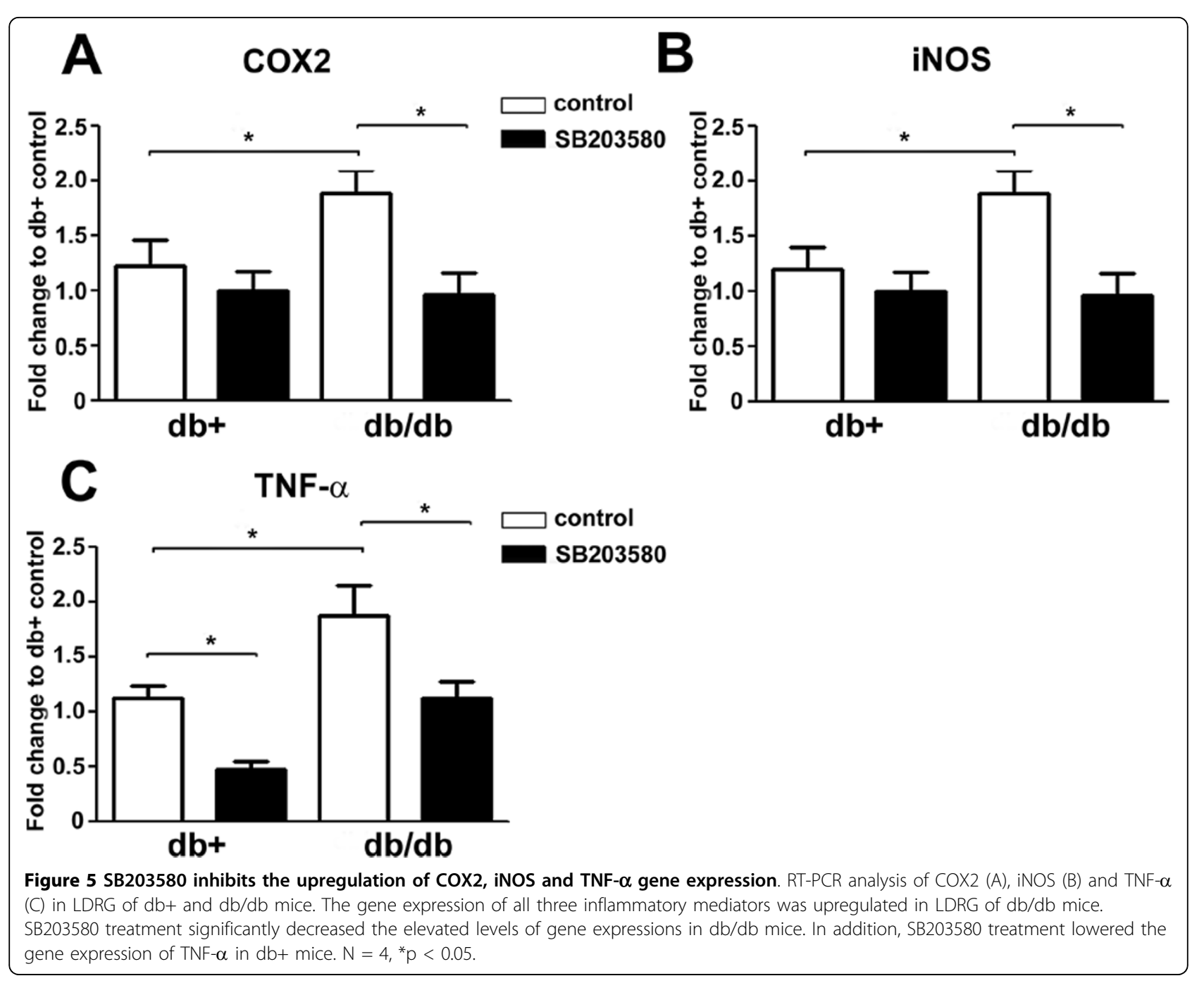

(Fig. 7B), and TNF- $\alpha$ (Fig. 7C). Increased percentages of neurons positive for all three molecules in $\mathrm{db} / \mathrm{db}$ mice were observed in comparison to $\mathrm{db}+$. In $\mathrm{db} / \mathrm{db}$ mice, SB203580 significantly decreased the percentages of COX2, iNOS, and TNF- $\alpha$ positive LDRG neurons.

Immunoblots of COX2, iNOS, and TNF- $\alpha$ (Fig. 8A) were performed in order to quantify the levels of these inflammatory proteins. Densitometric analysis confirmed that the levels of COX2 (Fig. 8B), iNOS (Fig. 8C) and TNF- $\alpha$ (Fig. 8D) were increased in $\mathrm{db} / \mathrm{db}$ mice in comparison to levels detected in $\mathrm{db}+$ mice. SB203580 treatment inhibited this upregulation of inflammatory protein expression. However, in contrast to what is observed in $\mathrm{db} / \mathrm{db}$ mice, SB203580 treatment did not have an effect on the protein levels of $d b+$ mice (Fig. 8).

\section{Discussion}

P38 has been reported to mediate many types of pain [7]. Here we are the first to report a role for this protein kinase in mechanical allodynia associated with PDN in an animal model of type 2 diabetes. Previously, we reported that NGF-Trk A signaling is elevated in $\mathrm{db} / \mathrm{db}$ mice [15]. The current study focuses on the mechanism underlying this role of p38 kinase in PDN and demonstrates that $\mathrm{p} 38$ is phosphorylated via NGF signaling in DRG neurons in the type 2 diabetic model. In turn, NGF-mediated p38 phosphorylation leads to mechanical allodynia in the $\mathrm{db} / \mathrm{db}$ mouse by upregulation of multiple inflammatory mediators in LDRG.

Our results demonstrated the phosphorylation of p38 in DRG of $\mathrm{db} / \mathrm{db}$ mice at the early stage of mechanical allodynia. P38 phosphorylation was transient (from 5-10 wk) and in parallel with the increased NGF expression in DRG and the development of mechanical allodynia [15]. The cause of this p38 phosphorylation is unclear, although the effect appears to result from exposure to hyperglycemia. We previously found that p38 is activated in neurons in culture in high glucose conditions 


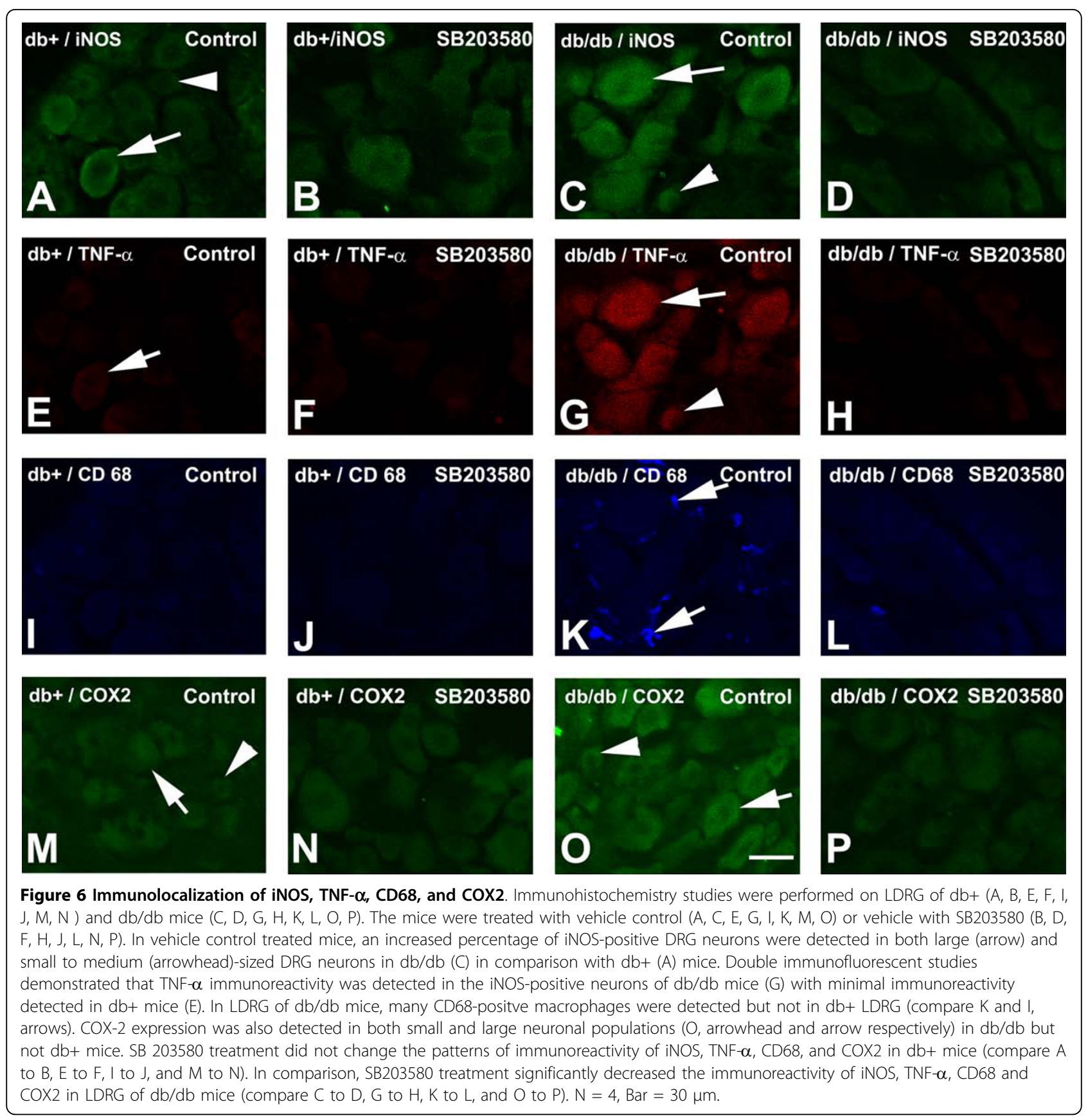

[18]. Phosphorylation of p38 is also reported in other tissues of $\mathrm{db} / \mathrm{db}$ mice [19]. Adhikary and colleagues detected p38 activation in kidneys of mouse models of type 1 and type $2(\mathrm{db} / \mathrm{db})$ diabetes, as well as kidneys of diabetic patients. Levels of pp38 in kidneys increased (2-6 fold) following the onset of diabetes in interstitial macrophages and myofibroblasts of $\mathrm{db} / \mathrm{db}$ mice in a manner that was associated with increased NGF expression downstream of hyperglycemia, and increased $\mathrm{HbA}$ (1)c. Our results demonstrate a comparable time course of p38 phosphorylation in DRG, suggesting similar mechanisms could be involved in the neuronal systems. In the current study, the p38 phosphorylation in DRG of $\mathrm{db} / \mathrm{db}$ mice returned to the control levels at $12 \mathrm{wk}$ of age. This reduction is likely a result from lack of NGF support at this stage [15]. Future studies using anti-diabetic agents will elucidate the role of hyperglycemia in the phosphorylation of p38 in DRG of $\mathrm{db} / \mathrm{db}$ mice.

Our findings of p38 phosphorylation parallel reports in a variety of inflammatory painful conditions, including osteoarthritic pain [20], bone pain [21], and complete Freund's adjuvant-induced inflammatory pain [22]. 


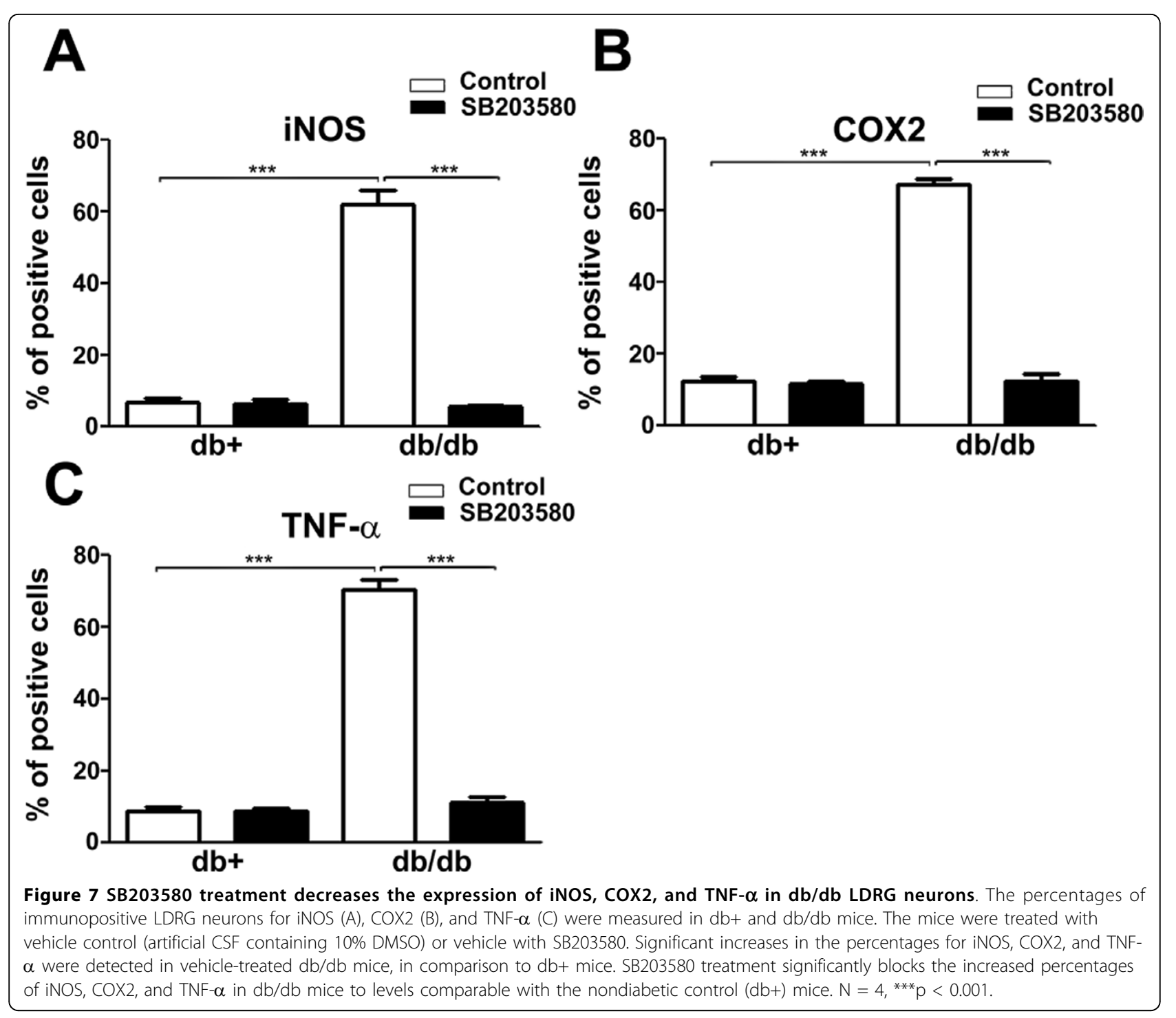

As predicted from our data, p38 is also involved in many neuropathic painful conditions, including nerve injury [13,23], neuropathic pain from type 1 diabetes [24], and central pain syndromes [25]. In the peripheral nervous system, p38 is activated in primary sensory DRG neurons by noxious stimuli [26], inflammatory pain $[10,27]$ and nerve injuries $[28,29]$.

In the current study, we found that p38 is phosphorylated in small- to medium- sized LDRG neurons during the period of mechanical allodynia in $\mathrm{db} / \mathrm{db}$ mice. Our findings are consistent with those of the STZ model of type 1 diabetic pain $[14,24]$, Obata and colleagues reported that most pp38 immunoreactivity is detected in small to medium-sized neurons, which also corresponds with our findings. $[26,29]$. In the spinal cord of similar pain models, pp38 immunoreactivity is detected in microglia, secondary sensory neurons, and astrocytes [7].
We demonstrate that NGF is an important factor to induce $\mathrm{p} 38$ activation in $\mathrm{db} / \mathrm{db}$ mice. Anti-NGF treatment completely blocked p38 phosphorylation in LDRG in db/ $\mathrm{db}$ mice and subsequent mechanical allodynia. NGF activates $\mathrm{p} 38$ in primary DRG neurons $[10,30]$. It has been proposed that NGF-activated p38 could increase the expression of transient receptor potential vallinoid (TRPV) 1 receptor [10] and transient receptor potential subfamily A 1 receptor [30] to mediate thermal and cold hyperalgesia respectively. According to Puntambekar and Mukherjea, the p38-mediated TRPV1 upregulation is secondary to activation of the Trk A receptor and its downstream RAC1/NADPH oxidase pathway [31]. The consistent time course shared by $\mathrm{p} 38$ phosphorylation, NGF upregulation, and Trk A phosphorylation in LDRG strongly suggests that the NGF-Trk A/p38 pathway mediates mechanical allodynia in $\mathrm{db} / \mathrm{db}$ mice [15]. 


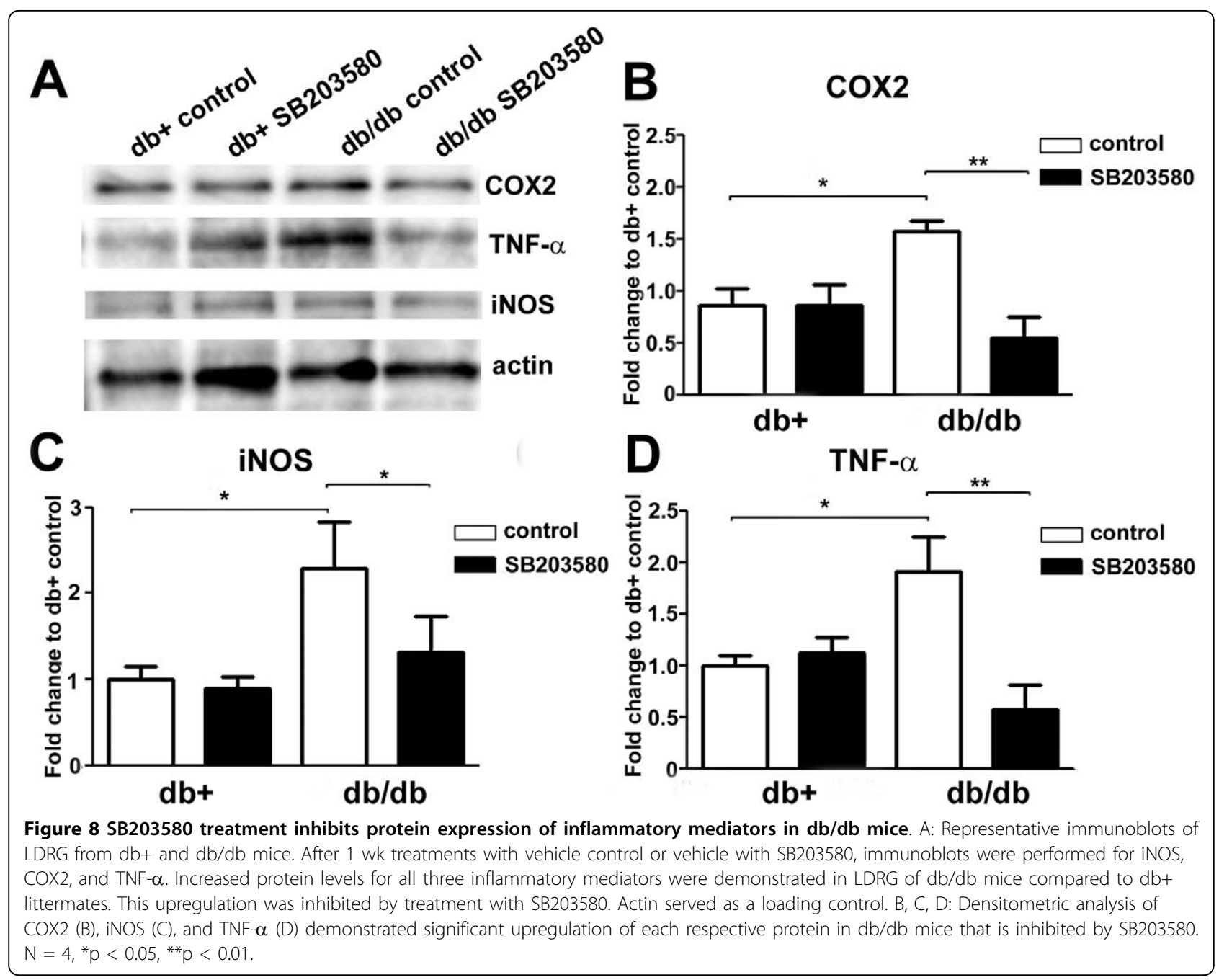

In the current study, we demonstrate that intrathecal administration of SB203580 completely blocks p38 phosphorylation and mechanical allodynia. Intrathecal administration of SB203580 blocks p38 phosphorylation in both DRG neurons and spinal cord cells (including neurons, astrocytes and microglia), according to previous studies $[13,14,32,33]$. In addition, other p38 inhibitors are used with the same result [24]. One caveat to our approach and that of our colleagues is that intrathecal administration of p38 inhibitors prevents p38 activation in both central and peripheral areas of the nervous system, thus the roles of site-specific p38 activation cannot be determined using this approach. As a result, we cannot eliminate the hypothesis that inhibitory effects of SB203580 on the development of PDN could result from effects in the spinal cord. Regardless, our findings support the use of p38 inhibitors for treating PDN of type 2 diabetes. Future studies should address the distinct roles of central versus peripheral p38 activation in PDN of type 2 diabetes.
We demonstrate that p38-mediated mechanical allodynia in $\mathrm{db} / \mathrm{db}$ mice is primarily mediated by small to medium-sized LDRG neurons that are immunopositive for SP. We previously reported that these SP-positive neurons are NGF-positive neurons with Trk A receptors [15]. Thus, our current results support the current hypothesis that NGF-dependent neurons are primarily responsible for the development of allodynia. In contrast, the numbers of IB4-labelled neurons are not affected in $\mathrm{db} / \mathrm{db}$ mice, suggesting that GDNF dependent neurons do not play a role in mediating mechanical allodynia in $\mathrm{db} / \mathrm{db}$ mice. These results are consistent with our previous findings that GDNF expression and the percentages of IB4-labelled neurons do not change in $\mathrm{db} / \mathrm{db}$ mice [15]. In parallel with our findings, NGF, but not GDNF-sensitive neurons, mediate discogenic pain [34]. According to Ramer and Bradbury, intrathecal injection of NGF treatment induces more extensive expression of the P2X3 receptor than GDNF in both DRG and spinal cord dorsal horn, and leads to chronic 
pain [35]. The upregulation of SP-positive neurons in our current study is reduced by SB203580, supporting our contention that p38 mediates SP-upregulation in the DRG of $\mathrm{db} / \mathrm{db}$ mice. There are two potential signaling mechanisms that may underlie this effect: 1) NGF may directly induce Trk A-dependent p38 phosphorylation, or 2) NGF could indirectly activate interleukin 1beta-dependent p38 activation to promote SP expression [36]. We are currently performing experiments to distinguish between these two possibilities.

Our findings suggest that there are inflammatory reactions that occur in DRG of type 2 diabetes. Specifically, we detected increasing macrophage infiltration as well as upregulation of multiple inflammatory mediators in LDRG of $\mathrm{db} / \mathrm{db}$ mice. Joachim and colleagues determined that NGF, a proinflammatory cytokine, induces inflammation in multiple tissues, including skin [37]. It is known that NGF administration to skin not only induces an inflammatory reaction but also increases the number of dermal SP and CGRP-positive nerve fibers. Previously, we have reported that there is increased NGF expression in dermal inflammatory cells and nerve fibers in $\mathrm{db} / \mathrm{db}$ mice, indicating that similar NGFmediated inflammation occurs in the skin of mice with type 2 diabetes [15]. Our current study provides further evidence that similar inflammation occurs in DRG of $\mathrm{db} / \mathrm{db}$ mice.

Our study demonstrated an upregulation of COX2 expression in DRG of $\mathrm{db} / \mathrm{db}$ mice. Kellogg et al reported increased COX2 expression in DRG of STZ rats, a model of type 1 diabetes and suggested potential roles of COX2 in the mediation of diabetic neuropathy, which is consistent with our findings [38]. COX2 also mediates other diabetic complications, including nephropathy [39]. In order to study COX2, Bujaslska et al used specific COX2 inhibitors to demonstrate that COX2 mediates hyperalgesia in the STZ model of type 1 diabetes. [40]. Our study demonstrates that COX2 expression is mediated by $\mathrm{p} 38$ in the DRG of $\mathrm{db} / \mathrm{db}$ mice. In support of our findings, Amaya and colleagues reported a p38dependent COX2 expression by IL-1 [27]. In contrast, Kitazawa et al demonstrated that C-peptide-induced COX2 upregulation is dependent on the PKC/IkappaB/ NF-kappaB signaling pathway in fibroblasts [41]. We acknowledge that there are multiple signaling mechanisms to regulate COX2 expression and at this time we can not exclude the PKC/IkappaB/NF-kappaB signaling pathway, which could be an upstream or downstream mechanism of p38 activation to increase COX2 expression.

We detected increased iNOS expression in DRG of $\mathrm{db} / \mathrm{db}$ mice and suggest this upregulation could be a mechanism of mechanical allodynia. In agreement with our hypothesis, iNOS knockout mice have increased resistance to diabetic neuropathic complications, including impaired nerve conduction velocities and small fiber sensory neuropathy, indicating that iNOS could be an important mediator of PDN [42]. There is evidence to imply that diabetes-induced increased NO levels result from cellular signaling via advanced glycation and lipoxidation end products (AGEs/ALEs) [43]. The increased NO levels likely contribute to tactile hyperalgesia in the STZ model of type 1 diabetes [44]. In support of our findings in type 2 diabetes, Bujalska et al reported that intrathecal administration of a specific inhibitor of iNOS, but not neuronal NOS, prevents hyperalgesia in STZ-induced type 1 diabetes [40].

We report that there is a p38-dependent TNF- $\alpha$ upregulation in DRG of $\mathrm{db} / \mathrm{db}$ mice. Sherry et al demonstrate that p38 also mediates augmented lipopolysaccharide induced TNF- $\alpha$ expression in peritoneal macrophages of $\mathrm{db} / \mathrm{db}$ mice [45]. In contrast to their findings, we detected increased DRG expression of TNF- $\alpha$ in neurons instead of in infiltrating macrophages. However, macrophages could contribute to both inflammation and pain by increasing interleukins in DRG, including, IL-6 [46], and IL-12 [47]. Our findings strongly suggest that NGF increases TNF- $\alpha$ expression via p38. However, other NGF-dependant signaling mechanisms have been reported to enhance TNF- $\alpha$ expression, including NFkappaB. In support of our results, neuronal-derived TNF- $\alpha$ expression is upregulated in DRG of nerve injury models $[48,49]$. One way that TNF- $\alpha$ could increase mechanical nociception is by activating $\mathrm{p} 38$ via the TNF receptor 1 to modulate the tetrodotoxin-resistant sodium channel in DRG [50]. This molecular mechanism could also occur in our model with elevated neuronal p38mediated-TNF- $\alpha$ expression which, in turn, could serve as an autocrine factor to cause secondary p38 activation via the cell surface TNF receptor 1 . The gene expression of TNF- $\alpha$ was decreased by SB203580 in db+ mice. In contrast, SB203580 did not alter COX2 or iNOS RNAs. The finding suggests that there is a baseline p38-mediated regulation of TNF- $\alpha$ expression. Baseline p38-mediated TNF- $\alpha$ may be regulated by the trivial NGF level in LDRG of control mice or via other pathways like IL- $\beta$ inhibition of G protein-coupled receptor kinase 2 (GRK2) [51].

In summary, the current study demonstrates the phosphorylation of p38 and the upregulation of multiple inflammatory mediators including COX2, iNOS, and TNF- $\alpha$ in DRG neurons of $d b / d b$ mice. Our data suggest that inflammation in DRG could mediate mechanical allodynia in type 2 diabetes. While current guidelines for treating PDN only use neuropathic pain regimens [52], our results suggest that a combination of both neuropathic and anti-inflammatory therapies that target COX2, iNOS, and TNF- $\alpha$ will improve the current 
standard treatment for PDN of type 2 diabetes. Since p38 mediates multiple inflammatory mediators in PDN of type 2 diabetes, clinical studies using p38 inhibitors could potentially provide a better approach than using multiple inhibitors for mediators downstream of this mechanism to alleviate PDN of type 2 diabetes [53].

\section{Methods}

\section{Animals}

Male C57BLKS db/db mice were purchased from Jackson Laboratories (Bar Harbor, Maine; stock number 000662). The homozygous $\left(\right.$ Lepr $^{d b} /$ Lepr $^{d b}$, or $\left.\mathrm{db} / \mathrm{db}\right)$ mice were used as a model of type 2 diabetes, while heterozygous mice $\left(\mathrm{Lepr}^{d b} /+\right.$, or $\left.\mathrm{db}+\right)$ served as nondiabetic controls. Analyses and procedures were performed in compliance with protocols established by the Animal Models of Diabetic Complications Consortium (AMDCC) http://www.amdcc.org and were approved by the Use and Care of Animals Committee at the University of Michigan. All possible efforts were made to minimize the animals' suffering and the number of animals used.

\section{Mechanical Allodynia}

The animals were placed in a Plexiglas cage with mesh flooring and allowed to acclimate for $1 \mathrm{~h}$. A logarithmic series of calibrated monofilaments (Von Frey hairs; Stoelting, Wood Dale, IL) with bending forces from 1 to $10 \mathrm{~g}$ were applied to the mid-plantar surface of the hind paw and pressed to the point of bending. Brisk withdrawal of the stimulated paw was recorded as a positive response. Testing began with the $1 \mathrm{~g}$ filament, followed by larger filaments if no response was observed, using the up-down method [54], with a $10 \mathrm{~min}$. interval to allow the animals to recover between tests. Although all responses were noted, counting of the critical 6 data points did not begin until the response threshold was first crossed. The resulting pattern of the 6 positive and negative responses was tabulated, and the $50 \%$ gram threshold was calculated using the formula described previously [55]. Mechanical allodynia was determined by a significant decrease in the mechanical threshold of the $\mathrm{db} / \mathrm{db}$ mouse in comparison to that of a db+ littermate.

\section{Real time RT-PCR}

Total RNA was extracted from L4-6 DRG (LDRG) using the RNeasy Kit (Qiagen, Valencia, CA) according to the manufacturer's instructions. Six DRG (bilateral L4-6) were used for each animal and a total of 4 animals were used per condition. Reverse transcription was performed using the iScript cDNA Synthesis Kit (BioRad, Hercules, CA). Briefly, $5 \times$ iScript Reaction Mix, $1 \mu$ iScript Reverse Transcriptase and total RNA template were added to a final volume of $20 \mu \mathrm{l}$. Reaction conditions were $5 \mathrm{~min}$. at $25^{\circ} \mathrm{C}, 30 \mathrm{~min}$. at $42^{\circ} \mathrm{C}$ and $5 \mathrm{~min}$. at $85^{\circ} \mathrm{C}$. PCR was performed as described previously [56] using the primer sequences: COX2: sense $5^{\prime}$-GAT GAG CAA CTA TTC CAA ACC AG, antisense 5'-CCG CTC AGG TGT TGC ACG TAG; iNOS sense 5'-GGG CAG CCT GTG AGA CCT T, antisense 5'-TGA GGG CTC TGT TGA GGT CTA; TNF- $\alpha$ sense 5 '-AGC CGA TTT GCT ATC TCA TAC CAG, antisense 5'-CCT TCA CAG AGC AAT GAC TCC A; GAPDH sense 5'-TCC ATG ACA ACT TTG GCA TCG TGG-3', antisense 5'GTT GCT GTT GAA GTC ACA GGA GAC-3'.

All real-time PCR reactions were carried out in 96well PCR plates sealed with iCycler Optical Sealing Tape (BioRad). The PCR reactions contained 1× SYBR Green iCycler iQ mixture (BioRad), $0.2 \mu \mathrm{M}$ of each forward and reverse primer, and cDNA preparation to $25 \mu \mathrm{l}$ total volume. The PCR amplification profile was $94^{\circ} \mathrm{C}$ for $2 \mathrm{~min}, 35$ cycles of denaturation at $94^{\circ} \mathrm{C}$ for $30 \mathrm{~s}$, annealing at $60^{\circ} \mathrm{C}$ for $1 \mathrm{~min}$, and extension at $72^{\circ} \mathrm{C}$ for $30 \mathrm{~s}$, followed by $72^{\circ} \mathrm{C}$ for $5 \mathrm{~min}$. The mRNA expression levels of the genes were tested, and amplification and fluorescence detection were performed using iCycler iQ Real-time Detection System (BioRad). At the end of the PCR, melting curves were obtained from 46 subsequent temperature increments by measuring fluorescence every $10 \mathrm{~s}$ with $+0.5^{\circ} \mathrm{C} / \mathrm{step}$ increment, beginning at $72^{\circ} \mathrm{C}$. The quality of $\mathrm{PCR}$ products was determined by melting curve analysis. The fluorescence threshold value was calculated by the iCycler iQ system software, and the levels were normalized to values obtained for GAPDH. A non-template control [57] was run with every assay.

\section{Immunoblots}

Following deep anesthesia, L4-6 DRG were dissected from 4 mice per condition $(\mathrm{db} / \mathrm{db}$ and $\mathrm{db}+)$ and homogenized in ice-cold T-PER Tissue Protein Extraction Reagent (Pierce Biotechnology, Rockford, IL) containing protease inhibitors $(1 \mu \mathrm{M}$ sodium orthovanadate and $1 \mu \mathrm{M}$ sodium fluoride; Sigma Life Science, St. Louis, MO). Lysates were sonicated for $5 \mathrm{~s}$, centrifuged and processed for protein concentration using $D_{C}$ Protein Assay Reagents (BioRad). $50 \mu \mathrm{g}$ of protein were boiled in $2 \times$ sample buffer, separated on a SDS-PAGE gel, and transferred to a PVDF membrane. Membranes were blocked and incubated overnight at $4{ }^{\circ} \mathrm{C}$ with primary antibodies: phospho-p38 (pp38, 1:1000, rabbit polyclonal, Cell Signaling, Danvers, MA), total p38 (1:1000, rabbit polyclonal, Cell Signaling Danvers, MA), COX2 (1:1000, Cayman Chemical, Ann Arbor, MI), iNOS (1:1000, Abcam Inc, Cambridge, MA), and TNF- $\alpha$ (1:1000, Abcam, Cambridge, MA). Membranes were then rinsed and incubated with HRP-conjugated secondary antibodies for $1 \mathrm{~h}$ at $25^{\circ} \mathrm{C}$ and processed 
with chemiluminescence substrate (Thermo Fisher Scientific, Rockford, IL) before being exposed to Hyperfilm (Amersham, Piscataway, NJ). Densitometry was performed using Image $J$ software, and the results were normalized against actin densities from the same sample.

\section{Immunohistochemistry}

Four mice from each group $(\mathrm{db}+\mathrm{and} \mathrm{db} / \mathrm{db})$ were deeply anesthetized and perfused with $2 \%$ paraformaldehyde in phosphate buffered saline (PBS, pH 7.2, 0.1 M). L4-L6 DRG were dissected and post-fixed by immersion in $2 \%$ paraformaldehyde overnight at $4{ }^{\circ} \mathrm{C}$, then rinsed in graded sucrose solutions (5-30\% in PBS), embedded in mounting media (OCT), and flash-frozen in liquid nitrogen. Tissue sections $(10 \mu \mathrm{m})$ were cut and mounted onto SuperFrost Plus slides (Fisher Scientific, Pittsburgh, PA) and stored at $-80^{\circ} \mathrm{C}$ until ready for use. For immunolocalization, tissue sections were thawed on a warming plate $\left(55^{\circ} \mathrm{C}\right.$ for $\left.10 \mathrm{~min}\right)$, hydrated with PBS, and blocked in $0.1 \%$ TX-100 and 5\% non-fat dry milk in PBS. Sections were then incubated at room temperature for 16-24 h with primary antibodies: pp38 (1:1000), SP (Rat monoclonal, 1:500, Abcam), iNOS (1:1000), TNF- $\alpha$ (1:1000), or COX2 (1:1000). Sections were then rinsed 3 times in PBS and incubated with secondary antiserum conjugated with different fluorophores (AlexaFluor 488, 594, or 647, Invitrogen, Carlsbad, CA). Neurons were identified using NeuN antibody (1:250, Neuronal Nuclei, Alexa Fluor 488, Millipore, Temecula, CA). For IB4 labeling studies, the sections were incubated with AlexaFluor 594 labeled Griffonia simplicifolia Isolectin B-4 (1:500, Invitrogen) with 5\% non-fat dry milk in PBS for $1 \mathrm{~h}$. Sections were rinsed and mounted with ProLong ${ }^{\oplus}$ Gold antifade reagent (Invitrogen). To ensure specificity, sections were incubated with primary or secondary antisera alone to confirm there were no nonspecific immunoreactions. Fluorescent signals were examined using an Olympus FluoView 500 laser scanning confocal microscope.

The percentage of immunopositive cells was analyzed by counting the number of immunopositive neurons and multiplying by (100/total number of neurons). Cell size distribution studies were performed on the same image. A total of 6 LDRG from each animal were measured. Images of LDRG sections were captured with a Nikon camera (Nikon Microphoto-FXA), and the number of immunoreactive neuronal profiles was counted in a blinded fashion. Every tenth section was picked from a series of consecutive LDRG sections $(10 \mu \mathrm{m})$, and three to four sections were counted for each LDRG and expressed as the percentage of total neuronal profile measured by NeuN immunohistochemistry [10]. Sections were incubated with primary antisera alone, or secondary antisera alone, to ensure specificity. No significant nonspecific immunolabeling was detected in either control condition.

\section{Anti-NGF treatment}

To inhibit NGF action during the period of allodynia, we administered anti-NGF $(10 \mathrm{mg} / \mathrm{kg}$, mouse monoclonal antibody clone AS21, Exalpha Biologicals, Maynard, MA) or control IgG, intraperitoneally, once weekly to $\mathrm{db}+$ and $\mathrm{db} / \mathrm{db}$ mice at 6 and $7 \mathrm{wk}$ of age for $2 \mathrm{wk}$ $[15,58]$. L4-6 LDRG were collected at $8 \mathrm{wk}$ of age and processed for $\mathrm{pp} 38 / \mathrm{p} 38$ immunoblots.

\section{Minipump placement}

An osmotic minipump (Alzet minipump model 1007D, Duent Corporation, Cupertino, CA) was used for continuous intrathecal infusion into the lumbar spinal cord region. The $100 \mu \mathrm{l}$ volume minipump is designed with a $0.51 \mu \mathrm{l} / \mathrm{hr}$ infusion rate. The minipumps were filled with artificial cerebrospinal fluid (CSF) with $10 \%$ dimethyl sulfoxide (DMSO) with or without SB203580 $(1 \mathrm{mg} / \mathrm{ml}$, EMD Chemicals, Gibbstown, NJ). The minipumps were implanted into the dorsal subcutaneous space between the shoulder blades of each mouse at $7 \mathrm{wk}$ of age under sterile conditions. A caudally directed polyethylene cannula (Becton Dickinson and Company, Sparks, MD) was threaded subcutaneously at the level of the L5 spinal process. The L5 spinal process was removed and the tip of the cannula was then inserted into the subarachnoid space at the L5 level. The intrathecal infusion lasted for 1 wk at which time the mice reached 8 wk of age. Behavior studies were performed, followed by tissue collection.

\section{Data presentation and statistical analyses}

All data are presented as group means \pm SEM. The data between $d b+$ and $d b / d b$ mice of the same age were analyzed using the Mann-Whitney test. Statistical comparisons between different age groups were made by one-way ANOVA tests followed by a post hoc Tukey's multiple comparison test. A p-value of less than 0.05 was considered statistically significant.

\section{Acknowledgements \\ The authors thank Carey Backus, and Lisa McLean for technical assistance, Dr. Andrea Vincent for editing the revision. This work utilized the Morphology and Image Analysis Core of the Michigan Diabetes Research and Training Center funded by NIH (5P60 DK20572) from the National Institute of Diabetes \& Digestive \& Kidney Diseases. This study is supported by National Institutes of Health [UO1-DK60994 (ELF); 1K08NS061039 (HTC)] and the Juvenile Diabetes Research Foundation Center for the Study of Complications in Diabetes.}

\section{Authors' contributions}

HTC, JRD, JMH, SSO, and YH carried out the studies described. HTC and ELF contributed to designing the present study and analyzing the results. HTC, 
JRD, and ELF wrote the manuscript. All authors read and approved the final manuscript.

\section{Competing interests}

The authors declare that they have no competing interests.

Received: 15 January 2010 Accepted: 19 May 2010

Published: 19 May 2010

\section{References}

1. Boulton AJ, Vinik Al, Arezzo JC, Bril V, Feldman EL, Freeman R, Malik RA, Maser RE, Sosenko JM, Ziegler D: Diabetic neuropathies: a statement by the American Diabetes Association. Diabetes care 2005, 28:956-962.

2. Feldman EL, Stevens MJ, Russell JW, Peltier A, Inzucchi S, Porte JD, Sherwin RS, Baron A: Somatosensory neuropathy. The Diabetes Mellitus Manual McGraw-Hill 2005, 6:366-384.

3. Edwards JL, Vincent AM, Cheng HT, Feldman EL: Diabetic neuropathy: mechanisms to management. Pharmacology \& therapeutics 2008, 120:1-34.

4. Singleton JR, Smith AG, Russell J, Feldman EL: Polyneuropathy with Impaired Glucose Tolerance: Implications for Diagnosis and Therapy. CurrTreatOptionsNeurol 2005, 7:33-42.

5. Singleton JR, Smith $A G$, Bromberg MB: Painful sensory polyneuropathy associated with impaired glucose tolerance. Muscle \& nerve 2005, 24:1225-1228.

6. Barrett AM, Lucero MA, Le T, Robinson RL, Dworkin RH, Chappell AS: Epidemiology, public health burden, and treatment of diabetic peripheral neuropathic pain: a review. Pain medicine (Malden, Mass) 2007, 8(Suppl 2):S50-S62.

7. Ji RR, Gereau RWt, Malcangio M, Strichartz GR: MAP kinase and pain. Brain research reviews 2009, 60:135-148.

8. Obata K, Noguchi K: MAPK activation in nociceptive neurons and pain hypersensitivity. Life Sci 2004, 74:2643-2653

9. Cuenda A, Rousseau S: p38 MAP-kinases pathway regulation, function and role in human diseases. Biochim Biophys Acta 2007, 1773:1358-1375.

10. Ji RR, Samad TA, Jin SX, Schmoll R, Woolf CJ: p38 MAPK activation by NGF in primary sensory neurons after inflammation increases TRPV1 levels and maintains heat hyperalgesia. Neuron 2002, 36:57-68.

11. Sung CS, Wen ZH, Chang WK, Chan KH, Ho ST, Tsai SK, Chang YC, Wong CS: Inhibition of p38 mitogen-activated protein kinase attenuates interleukin-1beta-induced thermal hyperalgesia and inducible nitric oxide synthase expression in the spinal cord. Journal of neurochemistry 2005, 94:742-752.

12. Svensson Cl, Hua XY, Protter AA, Powell HC, Yaksh TL: Spinal p38 MAP kinase is necessary for NMDA-induced spinal PGE(2) release and thermal hyperalgesia. Neuroreport 2003, 14:1153-1157.

13. Tsuda M, Mizokoshi A, Shigemoto-Mogami Y, Koizumi S, Inoue K: Activation of p38 mitogen-activated protein kinase in spinal hyperactive microglia contributes to pain hypersensitivity following peripheral nerve injury. Glia 2004, 45:89-95.

14. Daulhac L, Mallet C, Courteix C, Etienne M, Duroux E, Privat AM, Eschalier A, Fialip J: Diabetes-induced mechanical hyperalgesia involves spinal mitogen-activated protein kinase activation in neurons and microglia via $\mathrm{N}$-methyl-D-aspartate-dependent mechanisms. Molecular pharmacology 2006, 70:1246-1254.

15. Cheng HT, Dauch JR, Hayes JM, Hong Y, Feldman EL: Nerve growth factor mediates mechanical allodynia in a mouse model of type 2 diabetes. $J$ Neuropathol Exp Neurol 2009, 68:1229-1243.

16. Hummel KP, Dickie MM, Coleman DL: Diabetes, a new mutation in the mouse. Science (New York, NY) 1966, 153:1127-1128.

17. Sullivan KA, Hayes JM, Wiggin TD, Backus C, Su Oh S, Lentz SI, Brosius F: Mouse models of diabetic neuropathy. Neurobiology of disease 2007, 28:276-285.

18. Cheng HL, Feldman EL: Bidirectional regulation of p38 kinase and c-Jun $\mathrm{N}$-terminal protein kinase by insulin-like growth factor-I. J Biol Chem 1998, 273:14560-14565.

19. Adhikary L, Chow F, Nikolic-Paterson DJ, Stambe C, Dowling J, Atkins RC, Tesch GH: Abnormal p38 mitogen-activated protein kinase signalling in human and experimental diabetic nephropathy. Diabetologia 2004, 47:1210-1222.

20. Brown KK, Heitmeyer SA, Hookfin EB, Hsieh L, Buchalova M, Taiwo YO, Janusz MJ: P38 MAP kinase inhibitors as potential therapeutics for the treatment of joint degeneration and pain associated with osteoarthritis. J Inflamm (Lond) 2008, 5:22.

21. Cottrell JA, Meyenhofer M, Medicherla S, Higgins L, O'Connor JP: Analgesic effects of p38 kinase inhibitor treatment on bone fracture healing. Pain 2009, 142:116-126.

22. Cheng HT, Suzuki M, Hegarty DM, Xu Q, Weyerbacher AR, South SM, Ohata $M$, Inturrisi CE: Inflammatory pain-induced signaling events following a conditional deletion of the $\mathrm{N}$-methyl-D-aspartate receptor in spinal cord dorsal horn. Neuroscience 2008, 155:948-958.

23. Hasegawa S, Kohro Y, Tsuda M, Inoue K: Activation of cytosolic phospholipase A2 in dorsal root ganglion neurons by $\mathrm{Ca} 2+/$ calmodulindependent protein kinase II after peripheral nerve injury. Mol Pain 2009, 5:22.

24. Sweitzer SM, Medicherla S, Almirez R, Dugar S, Chakravarty S, Shumilla JA, Yeomans DC, Protter AA: Antinociceptive action of a p38alpha MAPK inhibitor, SD-282, in a diabetic neuropathy model. Pain 2004, 109:409-419.

25. Crown ED, Gwak YS, Ye Z, Johnson KM, Hulsebosch CE: Activation of p38 MAP kinase is involved in central neuropathic pain following spinal cord injury. Exp Neurol 2008, 213:257-267.

26. Mizushima T, Obata K, Yamanaka H, Dai Y, Fukuoka T, Tokunaga A, Mashimo T, Noguchi K: Activation of p38 MAPK in primary afferent neurons by noxious stimulation and its involvement in the development of thermal hyperalgesia. Pain 2005, 113:51-60.

27. Amaya F, Samad TA, Barrett L, Broom DC, Woolf CJ: Periganglionic inflammation elicits a distally radiating pain hypersensitivity by promoting COX-2 induction in the dorsal root ganglion. Pain 2009, 142:59-67.

28. Lee KM, Jeon SM, Cho HJ: Tumor necrosis factor receptor 1 induces interleukin- 6 upregulation through NF-kappaB in a rat neuropathic pain model. Eur J Pain 2009, 13:794-806.

29. Obata K, Yamanaka H, Kobayashi K, Dai Y, Mizushima T, Katsura H, Fukuoka T, Tokunaga A, Noguchi K: Role of mitogen-activated protein kinase activation in injured and intact primary afferent neurons for mechanical and heat hypersensitivity after spinal nerve ligation. $J$ Neurosci 2004, 24:10211-10222.

30. Obata K, Katsura H, Mizushima T, Yamanaka H, Kobayashi K, Dai Y, Fukuoka T, Tokunaga A, Tominaga M, Noguchi K: TRPA1 induced in sensory neurons contributes to cold hyperalgesia after inflammation and nerve injury. The Journal of clinical investigation 2005, 115:2393-2401.

31. Puntambekar P, Mukherjea D, Jajoo S, Ramkumar V: Essential role of Rac1/ NADPH oxidase in nerve growth factor induction of TRPV1 expression. Journal of neurochemistry 2005, 95:1689-1703.

32. Cui XY, Dai Y, Wang SL, Yamanaka H, Kobayashi K, Obata K, Chen J, Noguchi K: Differential activation of p38 and extracellular signalregulated kinase in spinal cord in a model of bee venom-induced inflammation and hyperalgesia. Mol Pain 2008, 4:17.

33. Inoue K, Tsuda M, Koizumi S: Chronic pain and microglia: the role of ATP. Novartis Found Symp 2004, 261:55-64, discussion 64-57, 149-154.

34. Aoki Y, An HS, Takahashi K, Miyamoto K, Lenz ME, Moriya H, Masuda K: Axonal growth potential of lumbar dorsal root ganglion neurons in an organ culture system: response of nerve growth factor-sensitive neurons to neuronal injury and an inflammatory cytokine. Spine (Phila Pa 1976) 2007, 32:857-863.

35. Ramer MS, Bradbury EJ, McMahon SB: Nerve growth factor induces P2X(3) expression in sensory neurons. Journal of neurochemistry 2001, 77:864-875.

36. Igwe OJ: c-Src kinase activation regulates preprotachykinin gene expression and substance $P$ secretion in rat sensory ganglia. Eur J Neurosci 2003, 18:1719-1730.

37. Joachim RA, Kuhlmei A, Dinh QT, Handjiski B, Fischer T, Peters EM, Klapp BF Paus R, Arck PC: Neuronal plasticity of the "brain-skin connection": stresstriggered up-regulation of neuropeptides in dorsal root ganglia and skin via nerve growth factor-dependent pathways. J Mol Med 2007, 85:1369-1378.

38. Kellogg AP, Cheng HT, Pop-Busui R: Cyclooxygenase-2 pathway as a potential therapeutic target in diabetic peripheral neuropathy. Curr Drug Targets 2008, 9:68-76.

39. Yabuki A, Tahara T, Taniguchi K, Matsumoto M, Suzuki S: Neuronal nitric oxide synthase and cyclooxygenase- 2 in diabetic nephropathy of type 2 diabetic OLETF rats. Exp Anim 2006, 55:17-25. 
40. Bujalska M, Tatarkiewicz J, Corde de A, Gumulka SW: Effect of cyclooxygenase and nitric oxide synthase inhibitors on streptozotocininduced hyperalgesia in rats. Pharmacology 2008, 81:151-157.

41. Kitazawa M, Shibata Y, Hashimoto S, Ohizumi Y, Yamakuni T: Proinsulin Cpeptide stimulates a PKC/lkappaB/NF-kappaB signaling pathway to activate COX-2 gene transcription in Swiss 3T3 fibroblasts. J Biochem 2006, 139:1083-1088.

42. Vareniuk I, Pavlov IA, Obrosova IG: Inducible nitric oxide synthase gene deficiency counteracts multiple manifestations of peripheral neuropathy in a streptozotocin-induced mouse model of diabetes. Diabetologia 2008, 51:2126-2133.

43. Cameron NE, Gibson TM, Nangle MR, Cotter MA: Inhibitors of advanced glycation end product formation and neurovascular dysfunction in experimental diabetes. Annals of the New York Academy of Sciences 2005, 1043:784-792.

44. Khan N, Bakshi KS, Jaggi AS, Singh N: Ameliorative potential of spironolactone in diabetes induced hyperalgesia in mice. Yakugaku Zasshi 2009, 129:593-599.

45. Sherry CL, O'Connor JC, Kramer JM, Freund GG: Augmented lipopolysaccharide-induced TNF-alpha production by peritoneal macrophages in type 2 diabetic mice is dependent on elevated glucose and requires p38 MAPK. J Immunol 2007, 178:663-670.

46. Thieringer R, Fenyk-Melody JE, Grand Le CB, Shelton BA, Detmers PA, Somers EP, Carbin L, Moller DE, Wright SD, Berger J: Activation of peroxisome proliferator-activated receptor gamma does not inhibit IL-6 or TNF-alpha responses of macrophages to lipopolysaccharide in vitro or in vivo. J Immunol 2000, 164:1046-1054.

47. Wen Y, Gu J, Li SL, Reddy MA, Natarajan R, Nadler JL: Elevated glucose and diabetes promote interleukin-12 cytokine gene expression in mouse macrophages. Endocrinology 2006, 147:2518-2525.

48. Xu JT, Xin WJ, Zang Y, Wu CY, Liu XG: The role of tumor necrosis factoralpha in the neuropathic pain induced by Lumbar 5 ventral root transection in rat. Pain 2006, 123:306-321.

49. Schafers M, Geis C, Brors D, Yaksh TL, Sommer C: Anterograde transport of tumor necrosis factor-alpha in the intact and injured rat sciatic nerve. $J$ Neurosci 2002, 22:536-545.

50. Jin X, Gereau RWt: Acute p38-mediated modulation of tetrodotoxinresistant sodium channels in mouse sensory neurons by tumor necrosis factor-alpha. J Neurosci 2006, 26:246-255.

51. Kleibeuker W, Gabay E, Kavelaars A, Zijstra J, Wolf G, Ziv N, Yirmiya R, Shavit Y, Tal M, Heijnen CJ: IL-1 beta signaling is required for mechanical allodynia induced by nerve injury and for the ensuing reduction in spinal cord neuronal GRK2. Brain Behav Immun 2008, 22:200-208.

52. O'Connor AB, Dworkin RH: Treatment of neuropathic pain: an overview of recent guidelines. Am J Med 2009, 122:S22-S32.

53. Coulthard LR, White DE, Jones DL, McDermott MF, Burchill SA: p38(MAPK): stress responses from molecular mechanisms to therapeutics. Trends $\mathrm{Mol}$ Med 2009, 15:369-379.

54. Dixon WJ: Efficient analysis of experimental observations. Annu Rev Pharmacol Toxicol 1980, 20:441-462.

55. Chaplan SR, Bach FW, Pogrel JW, Chung JM, Yaksh TL: Quantitative assessment of tactile allodynia in the rat paw. J Neurosci Methods 1994, 53:55-63.

56. Kabashi E, Agar JN, Hong Y, Taylor DM, Minotti S, Figlewicz DA, Durham HD: Proteasomes remain intact, but show early focal alteration in their composition in a mouse model of amyotrophic lateral sclerosis. Journal of neurochemistry 2008.

57. Feugeas JP, Dosquet C, Wautier JL, Montchamp-Moreau C, Krishnamoorthy R, Caillens H: [Dysregulation of in vitro TNF-beta production in insulin-dependent diabetes mellitus]. C R Acad Sci III 1993, 316:1255-1259.

58. Wild KD, Bian D, Zhu D, Davis J, Bannon AW, Zhang TJ, Louis JC: Antibodies to nerve growth factor reverse established tactile allodynia in rodent models of neuropathic pain without tolerance. J Pharmacol Exp Ther 2007, 322:282-287.

doi:10.1186/1744-8069-6-28

Cite this article as: Cheng et al:: p38 mediates mechanical allodynia in a mouse model of type 2 diabetes. Molecular Pain 2010 6:28.

\section{Submit your next manuscript to BioMed Central and take full advantage of:}

- Convenient online submission

- Thorough peer review

- No space constraints or color figure charges

- Immediate publication on acceptance

- Inclusion in PubMed, CAS, Scopus and Google Scholar

- Research which is freely available for redistribution

Submit your manuscript at www.biomedcentral.com/submit
C Biomed Central 